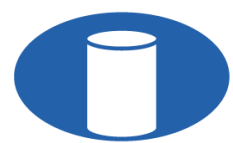

IBRACON

\title{
Experimental study of shear transfer in slim floor systems using precast concrete hollow core slabs and steel beam with web circular opening
}

\author{
Estudo experimental da transferência de forças de cisalhamento em pisos mistos de \\ pequena altura com lajes pré-fabricadas de concreto e viga em aço com abertura \\ circular na alma \\ Gustavo Coldebella ${ }^{a}$ \\ Sineval Esteves Pereira Junior ${ }^{\mathrm{a}}$ (D) \\ Silvana De Nardin ${ }^{\mathrm{a}}$

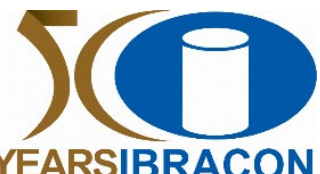

${ }^{a}$ Universidade Federal de São Carlos - UFSCar, Programa de Pós-Graduação em Engenharia Civil - PPGECiv, São Carlos, SP, Brasil

Received 26/02/2021

Accepted 20/10/2021

\begin{abstract}
Steel-concrete slim flooring system using precast concrete hollow core slabs and steel beam with web openings is an innovative construction system designed to combine the high bending resistance of both precast prestressed hollow core slabs and steel beam with web openings. This system can provide floor systems with a minimum constructional depth in comparison with ordinary composite floors. The aim of this study was to evaluate in an exploratory way the shear transferring mechanism between the steel beam with circular web opening and the precast hollow-concrete slab. The shear connection is formed by in-situ concrete passes through the web openings and infill the voids of the precast slabs. One push-out test was conducted to investigate the shear transferring mechanism of shear connection and the experimental results were compared to analytical methods. The shear resistance of the shear connection was predicted with good accurate by analytical methods.
\end{abstract}

Keywords: slim floor, push-out test, concrete hollow core slabs, beam with web opening, shear connection.

\begin{abstract}
Resumo: Piso misto de pequena altura com lajes alveolares e viga em aço com aberturas na alma é um tipo inovador de sistema construtivo projetado para aliar o alto desempenho estrutural das lajes pré-fabricadas de concreto protendido e das vigas em aço com aberturas na alma, proporcionando um pavimento de altura reduzida, comparado aos pisos convencionais. Este artigo tem como objetivo avaliar de forma exploratória a contribuição do efeito de pino de concreto como dispositivo mecânico de conexão entre a seção de aço e a laje de concreto. A análise foi realizada com base no resultado experimental de um ensaio de cisalhamento direto, que simula uma tipologia de conexão ao cisalhamento em pisos mistos com lajes alveolares de concreto e viga em aço com abertura circular na alma. Os resultados foram comparados com métodos analíticos. A capacidade resistente da conexão de cisalhamento apresentou boa aproximação com os valores previstos por métodos analíticos.
\end{abstract}

Palavras-chave: piso misto de pequena altura, ensaio de cisalhamento direto, lajes alveolares pré-moldadas de concreto protendido, viga com abertura na alma, estrutura mista.

How to cite: G. Coldebella, S. E. Pereira Junior, and S. De Nardin, "Experimental study of shear transfer in slim floor systems using precast concrete hollow core slabs and steel beam with web circular opening," Rev. IBRACON Estrut. Mater., vol. 15, no. 3, e15306, 2022, https://doi.org/10.1590/S1983-41952022000300006

Corresponding author: Sineval E. Pereira Junior. E-mail: sineval@estudante.ufscar.br

Financial support: This study was financed in part by the Coordenação de Aperfeiçoamento de Pessoal de Nível Superior - Brasil (CAPES) Finance Code 001. Conflict of interest: Nothing to declare.

Data Availability: The data that support the findings of this study are available from the author, SDN, upon request. 


\section{INTRODUCTION}

Recently, multistorey buildings have demanded solutions that combine structural efficiency to overcome long spans, economical construction and high productivity of construction processes [1]. The slim floor system is an innovative steel-concrete composite floor where the slab is supported on the lower flange of the steel beam resulting in a floor system with a minimum depth. This type of floor system can be composed by precast hollow core slabs and steel beam with circular web openings. The circular web openings of both, steel beam and precast hollow core units offer passage for the in-situ concrete creating interaction between the components and resulting in a composite section. Among the several types of composite floor systems, it is possible to highlight two configurations whose main difference is the position of the slab in relation to the beam. In conventional composite floor (Fig. 1a), the slab is supported on the top flange of the steel beam and the composite behavior is created by shear connectors welded on the top flange. In the composite slim floor system, the slab is embedded in the height of the steel beam resulting in flat appearance. The slim floor system (Fig. 1b) has advantages as height lower than the conventional composite floor, building service passage and fast construction. Both composite floor, conventional and slim floor, can be used several types of steel beams and slabs. Monosymmetric steel section with sequential web openings can be used in slim floor system; the behavior of this steel section depends on the shape and size of the openings. The choose of the better shape and size of the openings is based on the structural performance and saving materials. Sections with castellated and cellular openings are made by cutting the original steel profile longitudinally resulting in two parts. Then, these parts are welding together in a new configuration where the flanges are farther apart. The castellated beams have repeating hexagonal web openings, and this can increase the height of the original profile by two thirds, depending on the dimensions of the opening. Cellular beams are characterized by circular web openings allowing greater variety of spacing and diameters of the openings [2]. Moreover, the circular opening shape are suitable to pass building services.

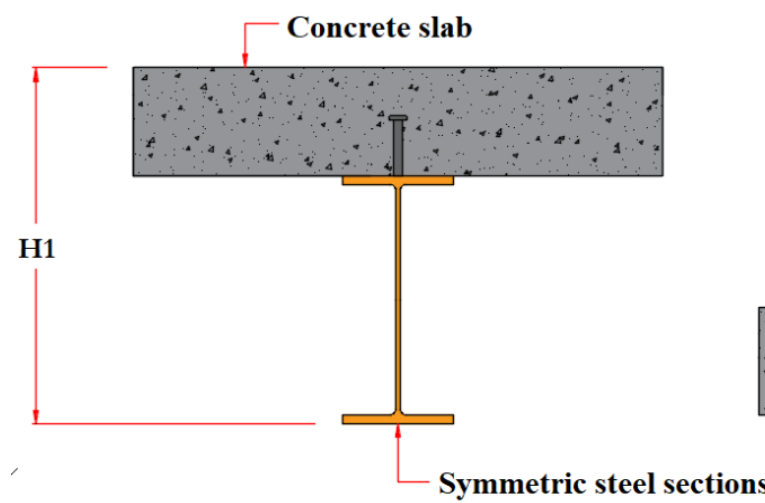

(a)

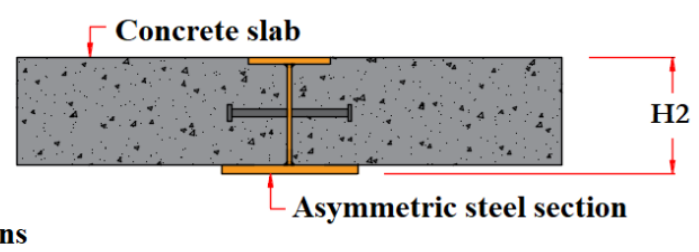

(b)

Fig. 1: Composite beam section - (a) conventional composite beam; (b) composite slim floor

The key feature of the composite slim floor system is that the steel cellular beam are contained within the concrete resulting in a system less susceptible to the local instabilities [3]. The concrete passing through the circular web openings of the steel profile provides the shear connection transferring the longitudinal forces between the components of the composite slim floor system. The infill concrete can be combined to with the additional steel reinforcing bar to increase the steel-concrete interaction. As the steel profile is embedded, partially or completely in the concrete, the steel-concrete shear connection is the result of concrete infill elements interact with web and steel reinforcing bar, associated with the bonding effect at the steel-concrete interface. The virtual shear connector to transfer the steel-concrete shear forces is different from conventional mechanisms [4].

In the composite slim floor system, the steel profile can be combines with several types of slabs. Solid concrete slabs, composite slabs with profiled steel decking (Fig. 2a) and prestressed hollow core slabs (Fig. 2b) are employed in slim floor systems. In comparison with the composite slim floor with composite slab, the use of pre-prestressed hollow core slabs increases the degree of industrialization and reduces the cast-in-place concrete. 


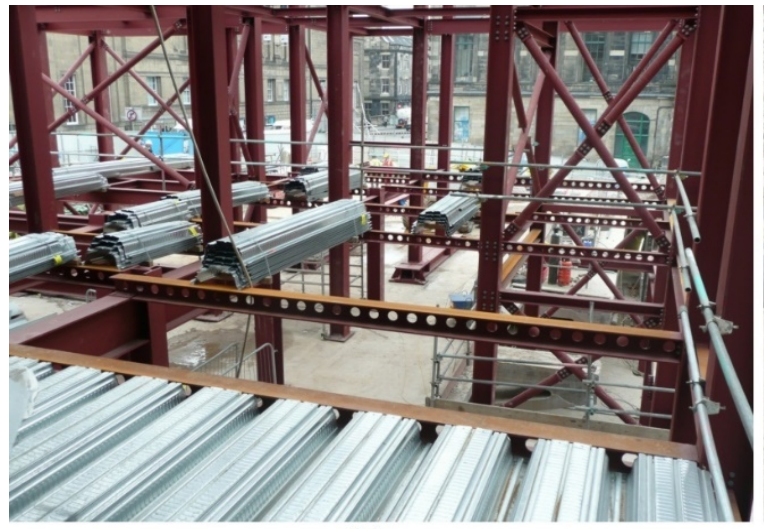

(a)

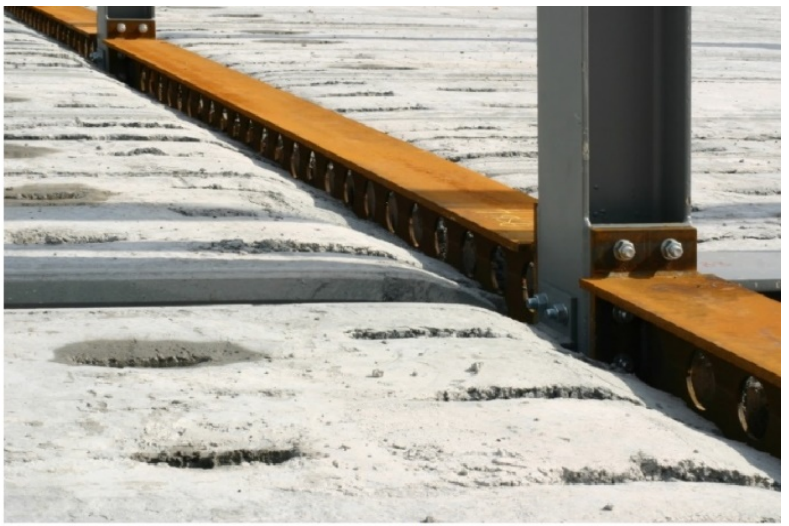

(b)

Fig. 2: Slim floor construction - (a) Steel decking [5]; (b) Precast hollow core slabs [6]

In summary, composite floor system formed by steel beam with web circular openings and precast hollow-core slabs can be an interesting structural solution. However, compared to conventional composite floor systems, there are several aspects of the structural behavior need to be investigated.

The main aim of this study is to analyze the shear connection provide by the through concrete in the large web opening of the steel beam, which forms an effect of concrete dowel. Studies of shear transfer mechanisms in composite slim floor systems with precast slabs often replace the precast slab by solid slabs. The innovation of this study is the precast slab that was included in the push out test. The exploratory study is based on experimental results of a push-out test. The geometry of specimen was developed taking account the Eurocode 4 [7]. The tested specimen represents a composite slim floor system formed by precast hollow-core slab and steel beam with web circular openings. The experimental results were compared with analytical methods developed to predict the shear resistance of shear connection.

\section{SHEAR TRANSFERRING MECHANISM ON COMPOSITE SLIM FLOOR SYSTEM}

The composite slim floor formed by precast hollow core slabs and steel beam with web circular openings takes advantage of the concrete filling the slab voids to shear forces transfer at the steel-concrete interface. The concrete passes through the web openings profile, completely filling the web openings and greatly contributing to the transfer of shear forces between the steel profile and the concrete slab. The steel beam with web circular openings is partially embedded in the concrete. Due this, the steel-concrete interaction is attributed to by concrete dowel effect (Fig. 3) or both, the concrete dowel and the steel bars immersed in the slab-beam opening. Different of shear transferring mechanisms promoted by the headed studs, in the composite slim floor the mechanism is formed by both, the concrete passing through the web openings of steel profile and tie bars.

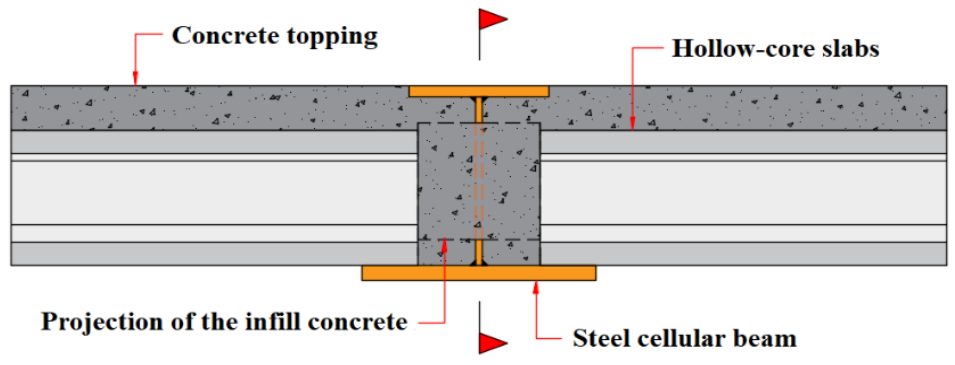

(a)

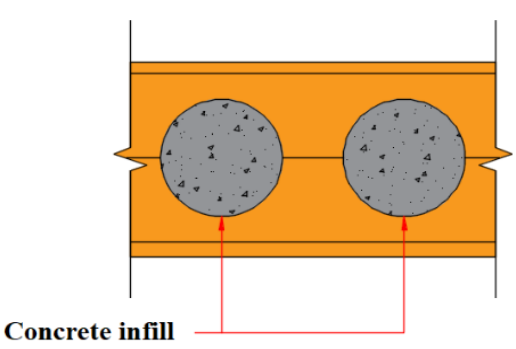

(b)

Fig. 3: Slim floor with precast hollow core slab and steel beam with web circular openings - (a) Cross section; (b) Section A - A 
The shear transfer at the first stages of loading is due to mechanisms such as chemical adhesion, friction and local compression, which are generated in the contact zone between components [4]. The steel profile is subjected to a longitudinal shear stress that induces bending and shear stresses in the section. With the load is increased, the shear resistance of the infill concrete in the web opening will be reached, and there may be a large slip at the interface between the steel beam and the concrete slab (Fig. 4), followed by the start of concrete cracking [4]. The transverse reinforcement embedded in concrete can contribute to improving the steel-concrete connection after cracking the slab [4]. The load continues increasing and causes the crack evolution process. At this stage, the transverse reinforcement resists the internal tensile stresses increasing the strength capacity of the shear connection and contributing to the redistribution of internal forces between the concrete slab and the steel beam.

The transverse reinforcement embedded in the concrete contributes is significant to the steel-concrete shear connection, however its use is not mandatory. Within this system, in which most of the beam is embedded in concrete, the bond shear resistance is enhanced significantly with the virtual concrete dowel formed by in-situ concrete passes through the continuous void of the slab and the web opening and fills the voids.

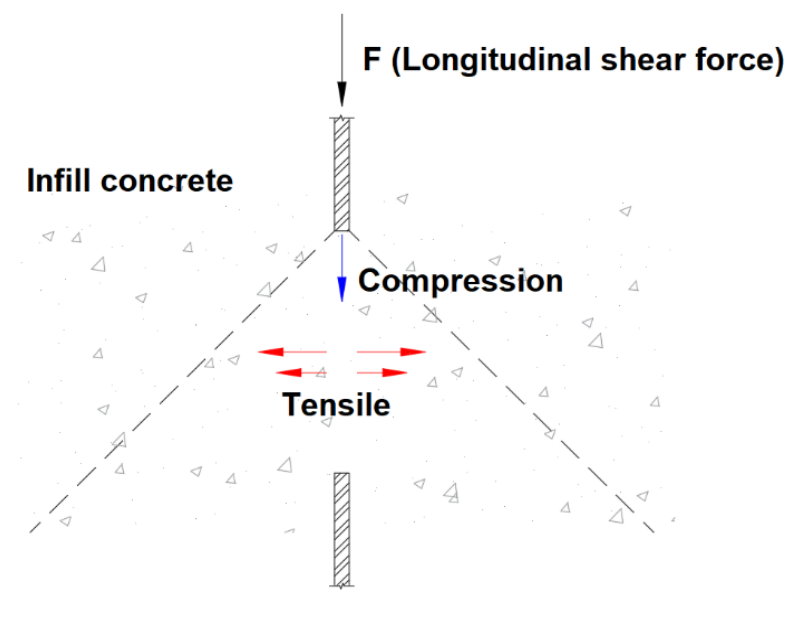

a) local compression force

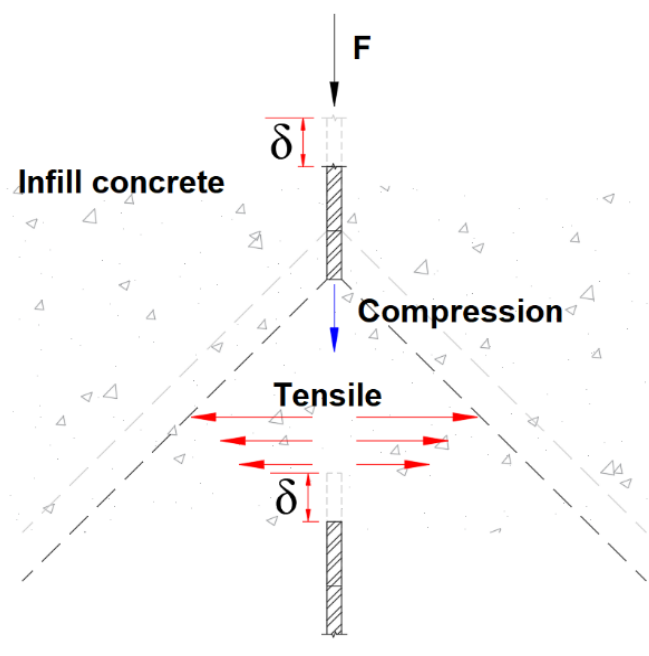

b) sliding action after concrete cracking by tensile

Fig. 4: Mechanism of transferring longitudinal force in shear connection - (a) Local compression force; (b) sliding action after concrete cracking by tensile

The push-out test [7] is the most common way to investigate the shear transferring mechanisms; the steel-concrete interface is evaluated under the direct longitudinal shear force. The ability of steel-concrete connection to transfer the longitudinal shear force and the contribution of mechanisms to controlling the slip at the steel-concrete interface can be evaluated in this type of test.

The Load vs. Slip response is very useful to evaluate the steel-concrete shear strength and connection ductility. Although the geometry of the specimen recommended by Eurocode 4 [7] is very different of the composite slim floor system, it was taken as the starting point to the present study. This is very common and employed for several researchers. For example, the shear transferring mechanisms in slim floor system comprising steel profile and prestressed concrete hollow core slabs was investigated by push-out tests [8]. The steel-concrete connection was provided by headed shear studs. The modified geometry was adequate to investigate the shear resistance and the ductility of the steel-concrete connection [8]. Regarding the steel-concrete transfer mechanism in composite slim floor formed by steel beam and solid slab between the profile flanges, several push-out test results were reported by Huo and D'Mello [9]. The chemical bond of steel-concrete was reduced applying grease on the surface of the steel profile in contact with the concrete. Two types of shear connection were investigated: concrete dowel (in-situ concrete completely fills the web openings) and the combination of concrete dowel and tie bars. The push-out test results had led to the development of a design method to estimate the shear resistance of the shear connection. This method is described in item 2.1.

In the present study the tested specimen is formed by a steel profile with circular web opening and precast hollow core concrete slabs. This difference in relation to the other studies introduces a series of complications in the assemblage of the specimen. Despite this, the specimen properly represents each component of the composite slim floor system. 
This study is important because there is a lack of studies about composite slim floor system including the precast concrete slab and the steel profile with web opening.

\subsection{Shear resistance capacity of shear connection}

Huo and D'Mello [9] developed an analytical procedure to estimate the shear resistance of the concrete infill element based on the failure mechanisms founded in the push-out tests. The failure mechanism was thus described: the top section of concrete infill was crushed by the web in shear direction and the other part of the concrete infill was ruptured by tensile splitting in the transverse direction [9]. The procedure combines both the compressive and tensile resistance (Table 1). Chen et al. [10] also developed an analytical procedure whose coefficients applied on compressive and tensile resistance of concrete infill element are the main difference in relation to Huo and D'Mello [9].

According to Chen et al. [10], the values 1.68 and 1.44 suggested by Huo and D'Mello [9]should be replaced respectively, by 1.30 and 1.15 when the slim floor is formed by composite decking and steel beam with web circular openings. A summary of design procedures $[9,10]$ is shown in Table 1 . The numerical coefficients (Table 1) on compressive and tensile resistance were determined from a set of tests carried out by Huo and D'Mello [9] and Chen et al. [10].

Table 1: Analytical procedures for shear longitudinal resistance

\begin{tabular}{|c|c|}
\hline Huo and D'Mello [9] & Chen et al. [10] \\
\hline \multicolumn{2}{|c|}{ Resistance force for one concrete dowel } \\
\hline$R_{c}=1.68 \cdot\left(f_{c u} \cdot A_{c}\right)+1.44 \cdot\left(f_{c t m} \cdot A_{t}\right)$ & $R_{c}=1.30 \cdot\left(f_{c u} \cdot A_{c}\right)+1.15 \cdot\left(f_{c t m} \cdot A_{t}\right)$ \\
\hline
\end{tabular}

A coefficient equal to 0.84 was obtained by Tran and Graubner [11] to convert the compressive strength from standard cylinder specimens to cube compressive strength and was applied in the present study.

\section{EXPERIMENTAL PROGRAM}

A specimen representing a composite slim floor system formed by a steel beam with one web circular opening and precast hollow core slabs was subjected to direct monotonic shear force. The Load vs. Slip behavior was obtained because of the pushout test. In the tested specimen the shear connection was only formed by the in-situ concrete completely fills the web opening without any additional steel bar. Therefore, the effect of concrete dowels was the main mechanism to resist the longitudinal shear.

\subsection{Specimens}

The tested specimen was composed by a steel profile with a circular web and precast hollow-core slabs. The circular opening was placed in the in the middle of the web height. (Fig. 5a). The geometry of the specimen was chosen taking the Eurocode 4 [7] as a reference. However, there are no specific recommendations for composite slim floor in Eurocode 4 [7].

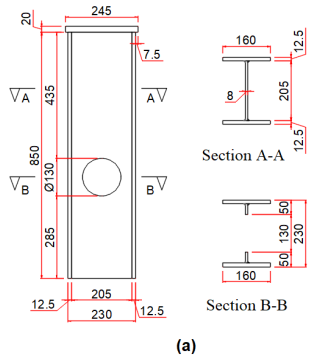

(a)

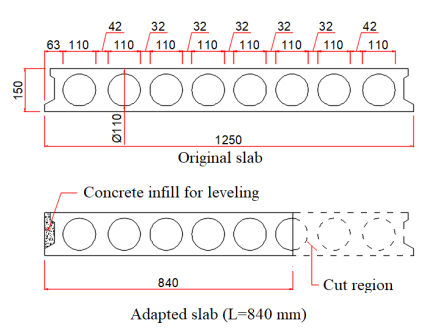

(b)

Fig. 5: Geometry of components - (a) Steel beam with web circular opening; (a) hollow core slab [mm] 
For this reason, the geometry of specimen was adjusted according to the characteristics of the slim floor. The position of the voids in precast slab and the shear connection mechanism were decisive factors to define the geometry. Fig. 5 and Fig. 6 given the geometry of specimen and the test setup. Recommendations of Lawson and Hicks [12] and the catalogue of ArcelorMittal [13] helped to select the geometry of the steel profile, including the opening diameter. The size of web openings was taken equal to $130 \mathrm{~mm}$ (Fig. 5a). The precast hollow-core concrete units (Fig. 5b) were donated by the company CASSOL Pré-fabricados LTDA. Some adjustments in the precast concrete units were necessary to match one of the slab voids with the circular opening of the steel profile (Fig. 5b). To regularize the slab edges which act as support during the test, the cut end was performed with industrialized grout (Fig. 5b). The bond between the steel and concrete was reduced with the use of grease on the surface of the steel profile before casting with concrete. The contribution of the adhesion for the shear transferring mechanism was decreased using this procedure.

The slab voids were filled with high fluidity in-situ concrete, in which only gravel 0 (granulometry $4.8 \mathrm{~mm}$ to $9.5 \mathrm{~mm}$ ) was used as coarse aggregate. All the voids of slabs were filled with in-situ concrete; however only one of them matches with the circular web opening of the steel profile. Hence, the shear resistance and behavior of the concrete dowel could be investigated.

The welded steel beam was fabricated by ASTM A36 and the main properties of the steel were determined by means of characterization tests carried out in accordance with ASTM E8/E8M-09 [14]. Mechanical properties of steel, concrete of precast slabs and in-situ concrete are given in Table 2 . The elasticity modulus of steel was assumed equal to $200 \mathrm{GPa}$ [15]. The concrete strength of the precast hollow-core slabs was provided by the manufacturer (Table 2). The other properties of the precast slabs were estimated from the prescriptions of ABNT NBR6118 [16].

Table 2: Material properties

\begin{tabular}{cccc}
\hline \multicolumn{4}{c}{ Steel beam } \\
\hline Component & Modulus of elasticity [GPa] & Yield strength [MPa] & Ultimate strength [MPa] \\
\hline Top and bottom flange & $200^{(1)}$ & $298.85^{(2)}$ & $421.52^{(2)}$ \\
\hline web & $200^{(1)}$ & $309.25^{(2)}$ & $428.99^{(2)}$ \\
\hline & Concrete slab & Tensile strength [MPa] \\
\hline Type & Modulus of elasticity [GPa] Cylinder compressive strength [MPa] & $3.51^{(3)}$ \\
\hline Hollow core slab & $35.42^{(3)}$ & $40^{(3)}$ & $2.28^{(2)}$ \\
\hline Infill concrete & $27.41^{(2)}$ & $34.06^{(2)}$ & C
\end{tabular}

${ }^{(1)}$ : theoretical values. ${ }^{(2)}$ : experimental values. ${ }^{(3)}$ : values provided by the manufacturer of the precast concrete slab

\subsection{Instrumentation and test setup}

The push-out test was performed on a static hydraulic jack of $1500 \mathrm{kN}$ capacity. A static vertical load was applied on the top end of the steel profile and vertical reactions on the base of the concrete slab allowed for the transfer of direct force to the shear connection by downward movement of the steel profile in load direction (Fig. 6d). The test was displacement-controlled, and the vertical load was continuously until the failure. The test was conducted in the Structures Laboratory of Engineering School at São Carlos/USP. 


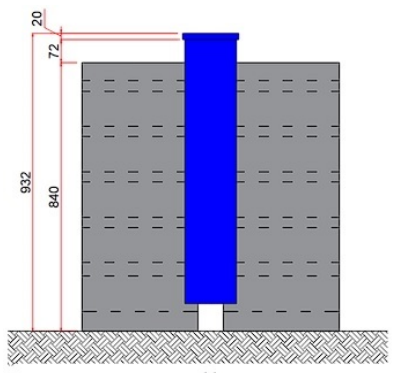

(a)

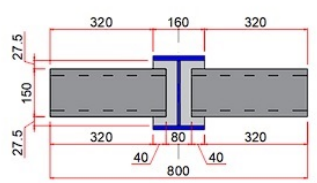

(c)

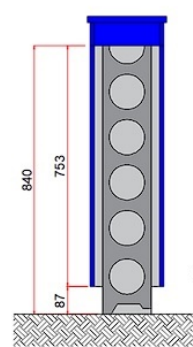

(b)

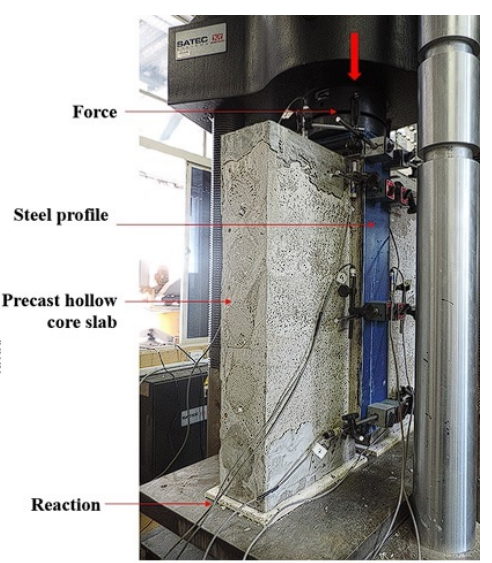

Fig. 6: Geometrical characteristics of composite cross-sections and setup of push out test - (a) Frontal view; (b) lateral view; (c) top view; (d) overview $[\mathrm{mm}]$

Six displacement transducers were positioned along the specimen to measure the relative displacements at the steel profile in relation to the precast concrete slab (Fig. 7c). The relative displacements were measure at the upper and lower ends of the hollow-core slab, on both sides (Fig. 7a). In Fig. 7, S and I indicate upper and lower, respectively; E and D are the left and right faces of the vertical axis of the steel profile, respectively. The letter $\mathrm{C}$ refers to the half-height section and the numbers 1, 2 and 3 are the positions; 1: left, 2: center and 3: right (Fig. 7b).

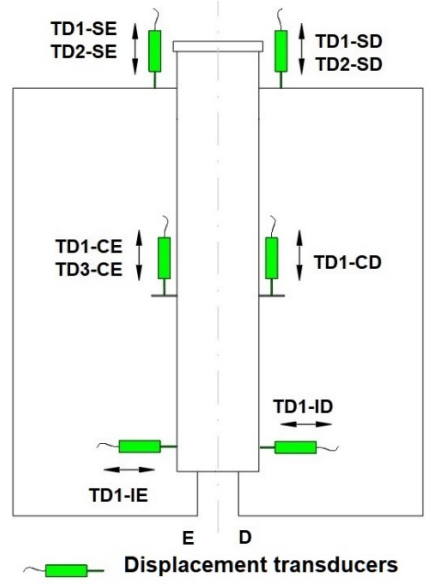

(a)

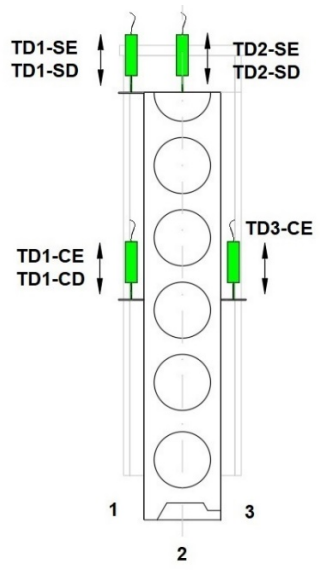

(b)

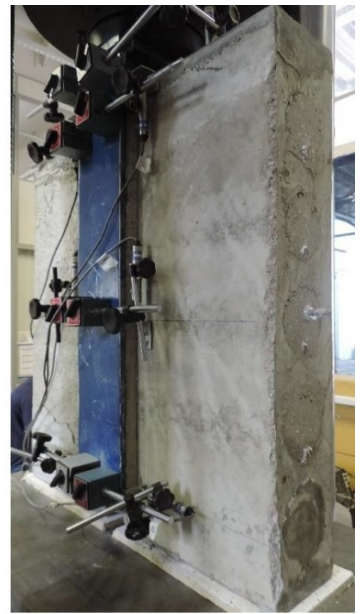

(c)

Fig. 7: Test setup and instrumentations of the push-out tests - (a) Frontal view; (b) lateral view; (c) Instrumented specimen

\section{RESULTS AND DISCUSSIONS}

\subsection{Load vs. Slip response}

To help, the Load vs. Slip curves of push-out test are presented in two ways for a better comprehension. First (Fig. $8 \mathrm{a}$ to Fig. 11a) the complete Load $v$ s. Slip curves are presented. After, in Fig. 8b-11b are highlighted the portions of the curves until the rupture of the concrete dowel limiting the slipping to $0.25 \mathrm{~mm}$.

The Load vs. Slip behavior (Fig. 8-11) can be divided into three phases. Values of load and corresponding steelconcrete slip are given in Table 3: 
Phase I: there was almost no steel-concrete slip up to the rupture of the infill concrete that corresponding to vertical load of $73.63 \mathrm{kN}$ (Fig. 8b). Thereafter, the load value immediately decreased to $60.80 \mathrm{kN}$ and the slip continues to increase.

> Phase II: the load increased again however slower than before, and large slips were recorded until the load was $76.09 \mathrm{kN}$. This load value was very similar to the concrete dowel rupture strength. Once again, slow decrease of the load was observed, and it reached $67.16 \mathrm{kN}$. The steel-concrete slip corresponding to the load decrease of Phase II was higher than in the Phase I (see Table 3).

> Phase III: the load becomes to increase, and the specimen carried maximum load of $80.44 \mathrm{kN}$. Large slips were induced after the ultimate load was reached.

According to Eurocode 4 [7], the slip should be measured at least until the load reaches to $20 \%$ below the ultimate load. However, this procedure was not performed because the load was kept almost constant while the steel-concrete slip was increased. Due this, the test was stopped after a long time in which the load was almost constant. Table 3 indicates the steel-concrete slip for three phases.

Table 3: Slip corresponding to the loading phases

\begin{tabular}{ccccccccc}
\hline \multirow{2}{*}{ Load [kN] } & \multicolumn{7}{c}{ Slip [mm] } \\
\cline { 3 - 9 } & TD1-SE & TD1-SD & TD2-SE & TD2-SD* & TD1-CE & TD1-CD & TD3-CE \\
\hline \multirow{2}{*}{ I } & 73.63 & 0.05 & 0.01 & 0.12 & 0.00 & 0.03 & 0.03 & 0.03 \\
\cline { 2 - 9 } & 60.80 & 0.10 & 0.02 & 0.16 & 0.02 & 0.07 & 0.05 & 0.06 \\
\hline \multirow{2}{*}{ II } & 76.09 & 2.44 & 0.65 & 2.61 & 0.68 & 2.39 & 0.65 & 2.34 \\
\hline & 67.16 & 6.33 & 4.46 & 6.49 & 4.51 & 6.32 & 4.30 & 9.25 \\
\hline III & 80.44 & 12.23 & 10.36 & 12.36 & 10.45 & 12.25 & 9.95 & 12.17 \\
\hline
\end{tabular}

* Corrected for absolute values

Similar slip behavior (Fig. 8a) was founded in all measured points (TD2-SE, TD1-SD, TD2-SD) at the top edge. The same was recorded in center line of the top edge (TD2-SE and TD2-SD, Fig. 9). Comparing the slip behavior on both, right and the left sides of the steel-concrete connection, nearly the same slip behavior were obtained in the test (Fig. 10). Therefore, the geometric imperfections of the specimen as well as the regularization of the model support base were insignificant for the slip.

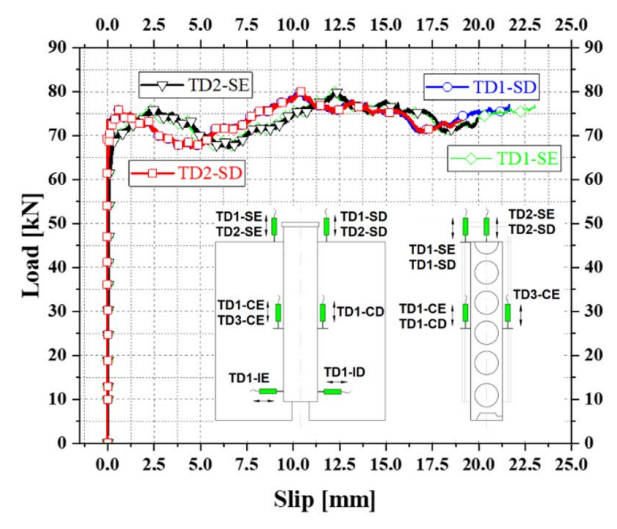

(a) General

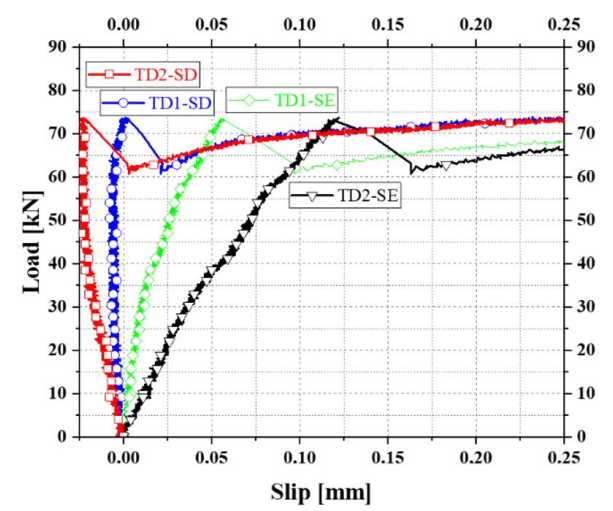

(b) First phase

Fig. 8: Load versus slip curves at the top of specimen

The slips recorded on TD1-SE and TD2-SE, both points on the upper left of the edge are very similar (Fig. 8a). Therefore, there was no significant asymmetry between the right and left sides of the specimen. Slips at the middle 
thickness of the slab were recorded by displacement transducers TD2-SE and TD2-SD (Fig. 7). The maximum values of slip recorded at left (TD2-SE) and right (TD2-SD) of the specimen were, respectively, $19.9 \mathrm{~mm}$ and $19.1 \mathrm{~mm}$ (Fig. 9). The slip values in all points are higher than $6 \mathrm{~mm}$ which indicates ductile behavior of the shear connection as outlined in the Eurocode 4 [7].

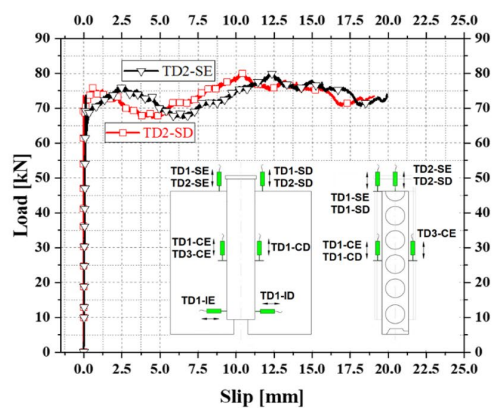

(a) General

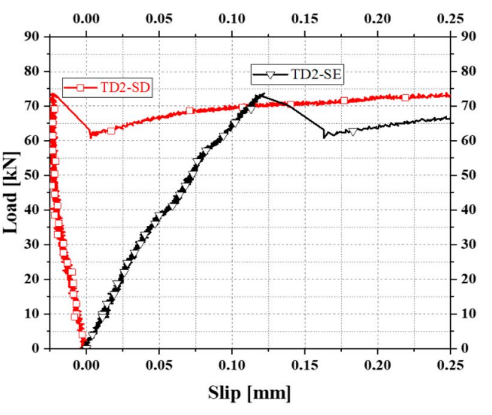

(b) First phase

Fig. 9: Load versus slip curves in point 2 at the top of specimen

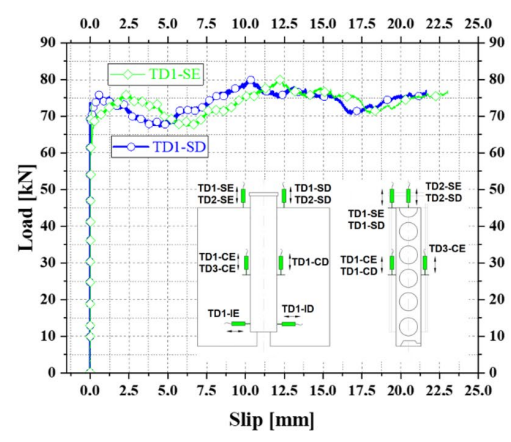

(a) General

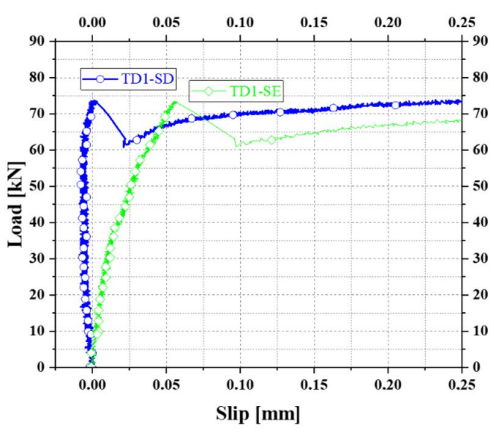

(b) First phase

Fig. 10: Load versus slip curves in point 1 at the top of specimen

The slip in half-length was also recorded by displacement transducers. Points TD1-CE and TD3-CE 1 (Fig. 11b) presented similar behavior until to the first peak load (limit of the Phase I). However, the slip values recorded in the point TD1-CD at right side of steel profile were lower than the others since the first peak load (limit of the Phase I). this can be observed in Fig. $11 \mathrm{~b}$ and Table 3.

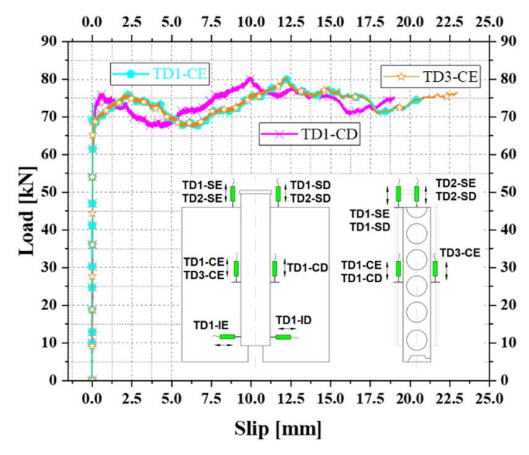

(a) General

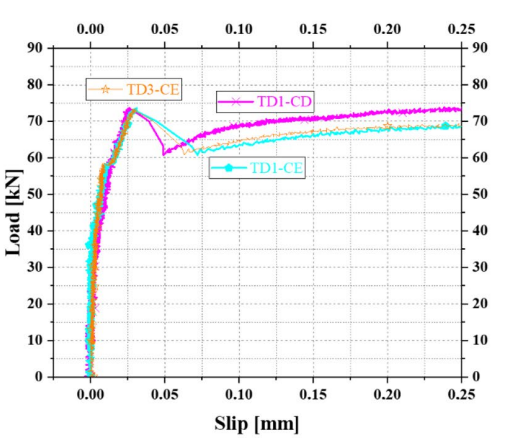

(b) First phase

Fig. 11: Load versus slip curves at the half length of the specimen 
Displacement transducers TD1-ID and TD1-IE recorded the horizontal steel-concrete separation, and the results are given in Fig. 12. The separation was measured at the bottom of the steel profile. Horizontal separation and steel-concrete slip presented the similar behavior up to the rupture of the concrete dowel. Thereafter, the behavior of right (TD1-ID, Fig. 12) and left (TD1-IE, Fig. 12) sides were not similar behavior. The loss of shear transferring of connection maybe indicates a loss of symmetry of the precast concrete slabs in relation to the steel profile. The horizontal separation at right side continues to increase up to the test end.

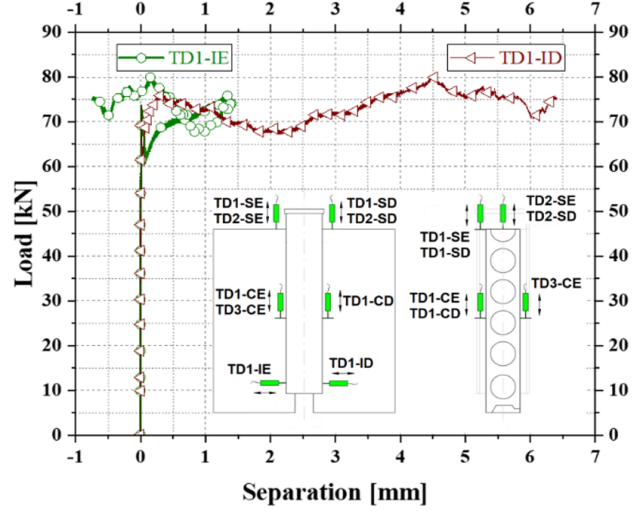

(a) General

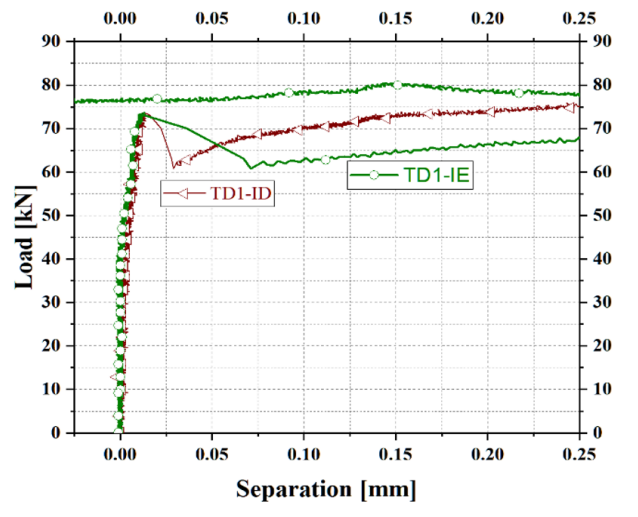

(b) First phase

Fig. 12: Horizontal separation between the steel profile and precast slab at the bottom of specimen

Regarding the failure mode, no cracks were observed in the precast concrete slabs. No visible failure was observed in the specimen and, apparently, the shearing of the virtual concrete dowel was the failure mode. This is compatible with the shear resistance value (Table 4) obtained considering one concrete dowel and the theoretical models described in item 2.1.

\subsection{Ultimate load}

The resistance of the concrete dowel $\left(\mathrm{R}_{\mathrm{c}}\right)$ was predicted with the analytical models presented in Table 1 . The theoretical values were compared to the ultimate load of the push-out test and the results are in Table 4.

Table 4: Comparison of experimental shear resistance and analytical results

\section{Shear resistance of one shear connection $R_{c}(k N)$}

\begin{tabular}{ccl}
\hline Experimental & \multicolumn{2}{c}{ Theoretical values } \\
\hline & Huo and D'Mello [9] & Chen et al. [10] \\
\hline 80.44 & $114.42(+42.2 \%)$ & $89.62(+11.4 \%)$ \\
\hline
\end{tabular}

The methods proposed by Huo and D'Mello [9] and Chen et al. [10] underestimated the shear resistance of the shear connection. Comparing the shear resistance capacity predicted using models of Huo and D'Mello [9] and Chen et al. [10] with the experimental result the differences were, respectively, $42.2 \%$ and $11.4 \%$ (Table 4 ). The difference between the shear resistance capacity predicted by analytical model of Chen et al. [10] was considered acceptable compared to experimental result.

In this exploratory study, it is not possible explain the reasons of the significant difference between experimental load and theoretical shear resistance capacity predicted by the calculation method of Huo and D'Mello [9]. 


\section{CONCLUSIONS}

The shear transfer mechanisms in composite slim floor system formed by precast hollow-core slabs and steel profile with web opening were investigated in the present study. The main objective was to evaluate the concrete dowel formed by the in-situ concrete that pass through and fill the opening of both, web of steel profile and voids of precast hollowcore slabs. The follow aspects are highlighted:

1) The Load vs. Slip curves showed that the chosen specimen type and the push-out test were adequate to investigate the shear transfer mechanism formed by the infill concrete in the web opening.

2) The shear connection formed by the concrete infill without any other elements demonstrated a ductile failure under the direct longitudinal shear force with a slip capacity of $19 \mathrm{~mm}$.

3) The analytical method of Chen et al. [10] showed good accuracy to predict the shear resistance of the shear connection between steel and concrete components of the composite slim floor system.

4) The proposed push-out test was efficient for evaluating the shear transferring mechanisms between the precast concrete hollow-core slab and the steel beam with web circular opening.

\section{ACKNOWLEDGMENTS}

This study was financed in part by the Coordenação de Aperfeiçoamento de Pessoal de Nível Superior - Brasil (CAPES) - Finance Code 001. The authors would also like to express their gratitude to CASSOL Pré-Fabricados Ltda for donating the precast hollow-core concrete slabs, Lafarge Holcim SA for the donation of cement, Soufer Industrial Ltda for the donation of steel plates and ConstruAço Construção Civil e Metálica São Carlos Ltda for welding the steel plates and compose the steel profile.

\section{REFERENCES}

[1] S. Chen and T. Limazie, "Composite slim floor beams with innovative shear connections," Proc. Inst. Civ. Eng., Struct. Build., vol. 171, no. 1, pp. 29-37, 2018.

[2] R. M. Lawson, F. Hanus, and D. Sonck, "Large web openings in steel and composite beams," Steel Constr., vol. 10, no. 2, pp. 168$175,2017$.

[3] S. De Nardin and A. L. H. C. El Debs, "Study of partially encased composite beams with innovative position of stud bolts," $J$. Construct. Steel Res., vol. 65, no. 2, pp. 342-350, 2009.

[4] T. Limazie and S. Chen, "Effective shear connection for shallow cellular composite floor beams," J. Construct. Steel Res., vol. 128, pp. 772-788, Jan 2017

[5] Steel Construction. "Ultra Shallow Floor Beam.” Steelconstruction.info. https://www.steelconstruction.info/File:Westok-3.jpg (accessed Mar. 13, 2019).

[6] Steel Construction. "Ultra Shallow Floor Beam.” Steelconstruction.info. https://www.steelconstruction.info/File:Westok2.jpg\#filelinks (accessed Mar.13, 2019).

[7] European Committee of Standardization, EN 1994-1-1: Eurocode 4 - Design of composite steel and concrete structures - Part 1-1: General rules and rules for buildings, 2004.

[8] P. T. Souza, Análise teórica e experimental de pisos mistos de pequena altura compostos por vigas metálicas e lajes alveolares de concreto, São Carlos: Universidade de São Paulo, 2016.

[9] B. Y. Huo and C. A. D’Mello, "Push-out tests and analytical study of shear transfer mechanisms in composite shallow cellular floor beams," J. Construct. Steel Res., vol. 88, pp. 191-205, 2013.

[10] S. Chen, T. Limazie, and J. Tan, "Flexural behavior of shallow cellular composite floor beams with innovative shear connections," $J$. Construct. Steel Res., vol. 106, pp. 329-346, 2015.

[11] N. L. Tran and C. A. Graubner, "Uncertainties of concrete parameters in shear capacity calculation of RC members without shear reinforcement," in 16th International Probabilistic Workshop., A. Strauss, K. Bergmeister, and D. Proske, Eds. Sep. 2018.

[12] R. M. Lawson and S. J. Hicks, Design of composite beams with large web openings, P355 ed. London: The Steel Construction Institute, 2011.

[13] ArcelorMittal, ACB Vigas alveolares. Madrid: APTA - Asociación para la Promoción Técnica del Acero, 2014.

[14] American Society for Testing and Materials, ASTM E8/E8M-09:2009. Standard test methode for tension testing of metallic materials., no T68, 2009.

[15] ASSOCIAÇÃO BRASILEIRA DE NORMAS TÉCNICAS, NBR 8800: Projeto de estruturas de aço e de estruturas mistas de aço e concreto de edificios, 2008. 
[16] ASSOCIAÇÃO BRASILEIRA DE NORMAS TÉCNICAS, ABNT NBR 6118: Projeto de estruturas de concreto - Procedimento, 2014.

Author contributions: GC: conceptualization, data curation; SEPJ: conceptualization, methodology, writing; SDN: funding acquisition, supervision data curation, formal analysis, methodology.

Editors: José Marcio Calixto, Guilherme Aris Parsekian 